$\xi \ldots$

\title{
The mediating effect of employee commitment towards organization effectiveness framework
}

\author{
Khairunesa Isa ${ }^{1}$, Rosman Md. Yusoff ${ }^{2}$, Abd. Rahman Ahmad ${ }^{3}$, Wan Hanim Nadrah Wan Muda ${ }^{4}$ \\ ${ }^{1,2,3,4}$ Universiti Tun Hussein Onn Malaysia' 86400 Parit Raja, Batu Pahat, Johor \\ Malaysia \\ *Corresponding author E-mail: nesa@uthm.edu.my
}

\begin{abstract}
The main purpose of this paper is to study the mediating effect of employee's commitment between leadership style and organization effectiveness. In addition, it presents a conceptual research framework to understand these relationships as supported by literature review from recent studies. The main findings indicate that employee commitment can be partial mediator factor between leadership style and organization effectiveness. To get the commitment, leaders should empower employees through human orientation and the application of transformational leadership elements such as intellectual stimulation and individual consideration which help to create mutual understanding between employees and organization. In conclusion, employee commitment plays a role as partial mediator between leadership style and organization effectiveness.
\end{abstract}

Keywords: Leadership Style; Partial Mediator; Employee Commitment; Organization Effectiveness

\section{Introduction}

Nowadays, firms are competing in a very dynamic business world to achieve sustainable growth. This global competitive environment has created the necessity for organizations to manage and preserve their workforce (1). Organizations that can compete with other organizations will be more effective. According to Midlemist and Hitt (2), the concept of organizational effectiveness refers to the organization's ability to manage and achieve objectives with a focus on relevance and future needs of the organization. In the context of organizations, leaders and workers have an equal role in determining the organization's ability to achieve goals. According to Ramchandran and Krishnan (3), the practice of leadership style adopted by the leader is one of the important factors in determining employees' commitment. In addition to affecting the organization, the leadership also affects followers in most things like making decisions, making changes or the desire to remain in the organization (4). Leaders and followers are human resources who are crucial in determining the achievement of organizational goals. Leadership aspect is closely related to a context where it is practiced. In addition to the background manager, the impact and influence of the leader on organizational performance and employee commitment is also often a problem in the field of organizational behavior. Leadership styles have a direct impact on employee commitment and success of the organization itself (5).

\section{Leadership Styles and Employees Com- mitment}

In today's world, leaders face a lot of challenges when changes occur.Hurduzeu (6) believed that effective leadership can affect economic growth and worker organizations despite the challenging environment. Nowadays, leaders must deal with employees who are more educated, exposed to the environment of modern life and have great regard towards the work done (7) as well good in arguing (8). All those challenges, encourage the leaders to change their leadership style to a more transformative force $(9,10)$ For example, in the context of public services, leaders should establish the concept of mutual understanding between leaders and followers through an act of intellectual stimulation and individual consideration of followers. Mutual understanding can stimulate and motivate followers to produce an outstanding output $(11,12)$ and then will enhance the organization's performance. This clearly shows that, the leadership style strongly influences the increase and decreasing of employee's commitment towards an organization (13). From another viewpoint, employee commitment is needed to ensure organizational goals can be achieved in line with the commitment position itself as one of the mechanisms in the measurement of the success of the organization (14). As a leader, it is important to ensure employee's goal is parallel with organization's goals so that it can affect the sense of belonging towards the organization besides facilitating the process in achieving the organization's goals. Leaders will also need to be aware of anything that drives employee's satisfaction (15), because employees who are satisfied with the work that they have done will feel more responsible for the task and at the same time, will show a strong commitment towards their jobs. Leaders who always tried to respond, ready to give recognition, are fair and always try to solve problems collaboratively with employees have a positive impact on the value and commitment of the employees in the organization(16). According to Igbaekemen (17), to ensure that the organization can continue its lifespan, the style of leadership that is able to stimulate employee commitment to the organization is required. In this context, democratic leadership style can improve organizational performance. 


\section{Commitment Roles in Employee Relations between Leadership and Organizational Effec- tiveness Framework}

Employee commitment affect the effectiveness of the organization (Steyrer at al., 2008), work performance and job turnover (18), prosocial behaviour (19) and non-attendance (20). According to Meyer and Allen (21) employee's commitment refers to the wants and needs of an employee to work and a desire to continue working in the organization with valid reasons. Commitment can be referred to as loyalty of workers to remain in the organization. Fear and threats to the organization including the effectiveness of the organization are dependent on their attitude and role. That is why, it can be said that employees' commitments are able to affect the effectiveness of the organization. This is because, employees who are committed to the organization will carry out a task on its own without the need for monitoring and direction from their leader $(22,23)$.

Ismail et al. (24) said, employee performance and organizational performance is measured by the extent of the commitment shown by the employees. This means that, if the commitment shown by employees are at highest level, then the performance of the employees will be on top and the organization performance will increase. It can be said that, employee's commitment is an important value in an organization (25) even though the commitment of workers is related to the high work turnover rate and absenteeism $(26,27)$ however, committed employees will still affect the performance of the organization. Because of that, it is important for an organization to ascertain factors that can encourage workers to stay committed towards the organization.

Meanwhile, the leadership style is also a fundamental part in mobilizing resources within the organization to improve organizational effectiveness (28-30). According to Jandaghi et al. (31), the style of leadership is not the sole factor contributing to the effectiveness of the organization as it still requires a mechanism as an intermediary in relations between leadership styles and effectiveness of the organization (28), such as organizational culture (32) and commitment (33). What is important is the participation of the leadership style needed in the long run to have a positive effect on employee commitment (34).

This discussion shows the commitment of the employees has its own role in achieving the organization performance. Similarly, Osabiya and Ikenga (35), tells of a significant relationship between employee performances in achieving the goals of the organization. So, this paper seeks to find out whether the role of employee commitment can be regarded as an intervener in the relationship between leadership style and organizational effectiveness chairman. This paper also tries to disclose the framework of studies showing the role of commitment in the relationship between leadership style and effectiveness of the organization in which the establishment of the framework of this study will involve three main items, including leadership style transformational and transactional leader, commitment and effectiveness of the organization to explain the relationship between each of the selected item. A total of three models and theories had been selected in building this framework, which are (i) Model Leadership Transformational and Transactional Bass (1985) used to describe the leadership style of the leader of the organization, (ii) Model Three Component Model of Employee Commitment Survey (TCM) by Meyer et al. (36)(1997) were used to measure the level of commitment in the organization and (iii) Index of Perceived organizational effectiveness (Poe) by Mott (37) used to describe and measure the effectiveness of an organization.

Development of this framework began with a discussion of the items in the style of transformational leadership and dealings (38), the dimensions of charismatic, individual consideration and intellectually stimulating for leadership dimensions of transformation while the dimensions of eligibility and manage exceptions refer to the dimensions of leadership style transaction. The rationale for the selection of all dimensions in transformational and transac- tional leadership style because all the dimensions in transformational and transactional leadership styles Bass (38) has a significant relationship with organizational effectiveness especially for the dimensions of charisma, intellectually stimulating and rewarding subject. All three of these dimensions are also capable of moving the workers to engage themselves in the process and work to achieve organizational goals without requiring leaders. Item on leadership style needs to rely on intermediaries in establishing items that can generate output and influence each other. While the item was selected, organizational effectiveness as items that received the influence of the impact of leadership styles and items of intermediary organizations. The concept is supported, backed up or influenced by measurement tool founded by the Mott (37), the Index of Perceived Organizational Effectiveness (PoE). According to Mott (1972) Poe instrument was used to measure the five main criteria for the competence of an organization's effectiveness in producing a product, quantity, quality, compatibility and flexibility. While each organization has its organizational effectiveness measurements that vary according to the direction of their respective organizations, nevertheless each of those features can still be represented with the dimensions as proposed by Mott.

While completing this framework development, workers have been committed as intervener item (mediator). Employees' commitment had been selected since employee commitment are able to contribute a lot to the organization and one of them can be seen as capable of affecting the relationship between leadership style and organizational performance (28). Employee commitment is an element that can play a role as mediator in the relationship between leadership style and organizational goals. Steyrer, Schiffinger (28) shows the existence of positive relationship between employee commitment to organizational effectiveness and employee commitment with the leadership style adopted by the leader.

Yousef (39) described that the elements of employee commitment are not only capable of being mediators in the relationship between leadership style with employee satisfaction and performance. However, employees' commitment also contributes to the organization's effectiveness. This is because the satisfaction and employee performance is measured between the elements of an organization's effectiveness $(27,40)$. According to Irefin and Mechanic (41), the commitment of our employees has a strong relationship with the organization's performance and turnover rates. Therefore, organizations should provide objective and realistic goals of the organization so that employees have a clear understanding of the purpose. In this context, it is the leadership's responsibility to determine that goal.

In elaborating the effectiveness of organizational commitment, Sabir et al. (42) stated that the chairman's leadership style has a strong relationship with each dimension of commitment. This relationship exists when employees felt that they have value in an organization. Employees who felt valued, recognized and have significant value to the organization will work best to produce a better impression of the organization (43). Nevertheless, there are studies which tried to question the role of commitment in affecting organizational effectiveness (44). According to Bennett (44), cultural factors strongly influenced the performance of the organization compared to the commitment of our employees. However, according to Xenikou and Simos (45) acceptance of the cultural aspects of the organization by employees is one indicator of commitment to the organization and acceptance of the culture directly affects work performance and organization. This situation indirectly still sees that the role of commitment could affect the performance and effectiveness of the organization.

Khan \& Rashid (46) stated that every element in the culture of the organization has different effects on employee commitment. However, both elements affect each other and have a relationship with organizational performance. The commitment given by the worker also known as one of the mechanisms of liaison between the organization's objectives to be achieved with the mission of personal and private beliefs of individuals. In other words, employees will more easily give a commitment to the organization if their goals 
are in line with the organization's goals. Employees like this are usually compelled to give a commitment to the organization voluntarily, without even having to wait for instructions or expecting reward from the organization. In contrast to workers who do not have personal goals in line with the organization, they will face difficulties in providing voluntary commitment. Workers in this group will feel obliged and even worse, they would only do the job based on the reward to be earned.

Jing and Avery (29) also suggested that a further study has be made to determine the significant elements that could be placed as an intermediate in the direct relationship between leadership style and organizational effectiveness. According to Jing and Avery (29) to determine the relationship between leadership style and organizational effectiveness, there is still a gap to be filled in order to facilitate the organization to achieve its goals. In this context,Jing and Avery (29) tried to see whether the employee's commitment can become a mediator in the relationship because the commitment is believed to be related to the effectiveness of the organization (47).

Based on the discussion above, employee's commitment is seen as a factor that has the potential to become a mediator in the relationship between leadership style and organizational effectiveness although at the same time commitment also has a relationship with the negative effects such as truancy and absenteeism. As a result, employee's commitment is also seen as a critical factor that can affect the effectiveness of the organization because there are also other factors that can affect as a mediator in the relationship between leadership style and effectiveness of the organization such as organizational culture (32) and personality of leader's organization (48).

Therefore, to ensure that workers can give commitments to the organization, stimulation of human relations-oriented leaders are able to encourage the followers to think about the importance of achieving the objectives of the organization and feel more valued in the organization. The discussion on the role of employee commitment as a mediator in the relationship between leadership style and organizational effectiveness can be seen more clearly in Figure 1 below.

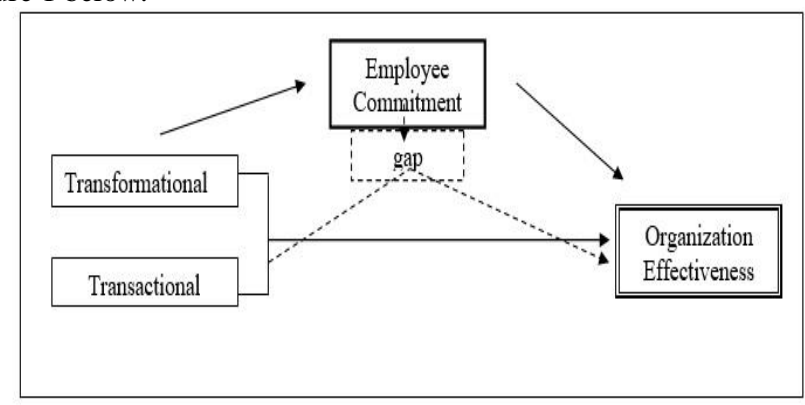

Petunjuk : $\longrightarrow$ Hubungan langsung antara pembolehubah ........ Hubungan tidak langsung (mediator) antara Pembolehubah

Fig. 1: Role of Employee Commitment as A Mediator

\section{Conclusion}

In conclusion, it can be concluded that, employee's commitment has its own role and effectiveness in the organization. It will be more significant if one is driven by other factors as a stimulus. In the context of this paper, the role of commitment of employees is important and necessary to ensure the continuity of the relationship between leadership style and organizational effectiveness. It is found that, employee's commitment was proven to promote the improvement and the achievement of organization performance through the stimulation of the transformational leadership style. Although the role of employee commitment can be detected in such a relationship, at the same time leaders must also ensure that the leadership style adopted is appropriate and capable of inducing employees to give their best to the organization's commitment. This is because effective leadership style is found capable of inducing workers to provide commitment and leadership style ori- ented human relationships were found to be easier to stimulate the minds of the workers openly to give a commitment to the organization and be happy.

\section{References}

[1] Hamid T, Mosalanejad R, Kargany SZ. The effect on turnover intention on empowering employees according to mediate the interoperability of PNU fars province employees. The Social Sciences. 2016;11(06):882-9.

[2] Middlemist RD, Hitt MA. Organizational behavior: Applied concepts: Sra; 1981.

[3] Ramachandran S, Krishnan VR. Effect of transformational leadership on followers' affective and normative commitment: culture as moderator. 2009

[4] Ponnu $\mathrm{CH}$, Tennakoon G. The association between ethical leadership and employee outcomes-the Malaysian case. EJBOElectronic Journal of Business Ethics and Organization Studies. 2009.

[5] Yukl G. An evaluation of conceptual weaknesses in transformational and charismatic leadership theories. The leadership quarterly. 1999;10(2):285-305.

[6] Hurduzeu R-E. THE IMPACT OF LEADERSHIP ON ORGANIZATIONAL PERFORMANCE. SEA: Practical Application of Science. 2015;3(1).

[7] Ahmad SZ, Abdul Rani NS, Mohd Kassim SK. Business challenges and strategies for development of small-and medium-sized enterprises (SMEs) in Malaysia. International Journal of Business Competition and Growth. 2010;1(2):177-97.

[8] Stewart DW, Sprinthall NA, Shafer DM. Moral development in public administration. Handbook of administrative ethics. 1994:325-48.

[9] Van Wart M. Handbook of training and development for the public sector: a comprehensive resource: ERIC; 1993.

[10] Medina FJ, Munduate L, Dorado MA, Martínez I, Guerra JM. Types of intragroup conflict and affective reactions. Journal of managerial psychology. 2005;20(3/4):219-30.

[11] Van Wart M. " Reinventing" In The Public Sector: The Critical Role Of Value Restructuring. Public Administration Quarterly. 1996:456-78

[12] Rani NSA, Pa'wan F, Musa NC, Tajudin MM. Malaysian Employees' Preference Of Their Managers Leadership Style. International Review of Business Research Papers. 2008;4(5):97108 .

[13] Blau GJ. The measurement and prediction of career commitment. Journal of Occupational and Organizational Psychology. 1985;58(4):277-88

[14] Abdullah M, Yasin MAMHM. Perbandingan Kompetensi Pengetua Sekolah antara Malaysia dan Indonesia. Sains Humanika. 2013;62(1).

[15] Mowday RT, Steers RM, Porter LW. The measurement of organizational commitment. Journal of vocational behavior $1979 ; 14(2): 224-47$

[16] Irving PG, Coleman DF, Cooper CL. Further assessments of a three-component model of occupational commitment: Generalizability and differences across occupations. Journal of applied psychology. 1997;82(3):444.

[17] Igbaekemen GO. Impact of leadership style on organisation performance: A strategic literature review. Public Policy and Administration Research. 2014;4(9):126-35

[18] Morita JG, Lee TW, Mowday RT. Introducing survival analysis to organizational researchers: A selected application to turnover research. Journal of Applied Psychology. 1989;74(2):280.

[19] O'Reilly CA, Chatman J. Organizational commitment and psychological attachment: The effects of compliance, identification, and internalization on prosocial behavior. Journal of applied psychology. 1986;71(3):492.

[20] Angle HL, Perry JL. Dual commitment and labor-management relationship climates. Academy of Management Journal. 1986;29(1):31-50.

[21] Meyer JP, Allen NJ. A three-component conceptualization of organizational commitment. Human resource management review. 1991;1(1):61-89.

[22] Paul A, Anantharaman R. Influence of HRM practices on organizational commitment: A study among software professionals in India. Human Resource Development Quarterly. 2004;15(1):7788 .

[23] Steers RM. Antecedents and outcomes of organizational commitment. Administrative science quarterly. 1977:46-56. 
[24] Ismail A, Mohamed HA-B, Sulaiman AZ, Mohamad MH, Yusuf MH. An empirical study of the relationship between transformational leadership, empowerment and organizational commitment. Business and Economics Research Journal. 2011;2(1):89.

[25] Armstrong M. A handbook of human resource management practice: Kogan Page Publishers; 2006.

[26] Guest DE. Personnel management: the end of orthodoxy? British journal of industrial relations. 1991;29(2):149-75.

[27] Baharudin O. Gaya Kepimpinan Pemimpin dan Komitmen Pekerja di Jabatan Agama Islam Selangor: Universiti Utara Malaysia; 2004.

[28] Steyrer J, Schiffinger M, Lang R. Organizational commitment-A missing link between leadership behavior and organizational performance? Scandinavian Journal of management. 2008;24(4):364-74.

[29] Jing FF, Avery GC. Missing links in understanding the relationship between leadership and organizational performance. International Business and Economics Research Journal. 2008;7(5):67.

[30] Flemming PL. A study of the relationship between transformational leadership traits and organizational culture types in improving performance in public sector organizations: A Caribbean perspective: Capella University; 2009.

[31] Jandaghi G, Matin HZ, Farjami A. Comparing transformational leadership in successful and unsuccessful companies. African Journal of Business Management. 2009;3(7):272.

[32] Weese WJ. Do leadership and organizational culture really matter? Journal of Sport Management. 1996;10(2):197-206.

[33] Bart CK, Bontis N, Taggar S. A model of the impact of mission statements on firm performance. Management decision. 2001;39(1):19-35.

[34] Iqbal N, Anwar S, Haider N. Effect of leadership style on employee performance. Arabian Journal of Business and Management Review. 2015;5(5)

[35] Osabiya B, Ikenga E. The Impact of Leadership Style on Employee's Performance in an Organisation. Public Policy and Administration Research. 2015;5(1):193-205.

[36] Meyer JP, Allen NJ, Allen NJ. Commitment in the workplace: Sage Publications; 1997.

[37] Mott PE. The characteristics of effective organizations: HarperCollins Publishers; 1972.

[38] Bass BM. Leadership and performance beyond expectations: Collier Macmillan; 1985

[39] Yousef DA. Organizational commitment and job satisfaction as predictors of attitudes toward organizational change in a nonwestern setting. Personnel review. 2000;29(5):567-92.

[40] Adeyemi-Bello T. The impact of leader characteristics on the performance of organizational members: an exploratory study. Work Study. 2003;52(6):286-9.

[41] Irefin P, Mechanic MA. Effect of employee commitment on organizational performance in Coca Cola Nigeria Limited Maiduguri, Borno state. Journal of Humanities and Social Science. 2014:33-41

[42] Sabir MS, Sohail A, Khan MA. Impact of leadership style on organization commitment: In a mediating role of employee values. Journal of Economics and Behavioral Studies. 2011;3(2):145-52.

[43] Meyer JP, Stanley DJ, Herscovitch L, Topolnytsky L. Affective, continuance, and normative commitment to the organization: A meta-analysis of antecedents, correlates, and consequences. Journal of vocational behavior. 2002;61(1):20-52.

[44] Bennett H. Employee commitment: the key to absence management in local government? Leadership \& Organization Development Journal. 2002;23(8):430-41.

[45] Xenikou A, Simosi M. Organizational culture and transformational leadership as predictors of business unit performance. Journal of managerial psychology. 2006;21(6):566-79.

[46] Khan SK, Rashid MZA. The Mediating Effect of Organizational Commitment in the Organizational Culture, Leadership and Organizational Justice Relationship with Organizational Citizenship Behavior: A Study of Academicians in Private Higher Learning Institutions in Malaysia. International Journal of Business and Social Science. 2012;3(8).

[47] Adhikari DR, Gautam DK. Employees' commitment and organizational performance in Nepal: A typological framework. SEBON Journal. 2011;5:1-17.

[48] Kinicki AJ, Prussia GE, Wu BJ, McKee-Ryan FM. A covariance structure analysis of employees' response to performance feedback. Journal of applied psychology. 2004;89(6):1057. 